\title{
SERVIER V EUROPEAN COMMISSION: FOLLOWING IN THE FOOTSTEPS OF LUNDBECK
}

\author{
Richard Tepper*
}

\begin{abstract}
In 2009, the European Commission's Competition Inquiry into the Pharmaceutical Sector focused on the competitive relationship between originator companies and generic undertakings. The Commission discovered that patent settlement agreements containing a reverse transfer of value from the originator to the generic undertaking were used to delay entry of generics into markets, limit consumers' choices, and burden public budgets. Since the Inquiry, the Commission adopted a more aggressive enforcement approach towards these patent settlements. In the recent Servier decision, it determined that the relevant agreements were in breach of Articles 101 and 102 TFEU. This commentary assesses the merits of Lundbeck's general rule on reverse payment settlements, evaluates the General Court's review of that decision in Servier and the exemption created for licensing agreements, and illustrates the difficulties in defining the relevant market for pharmaceutical products.
\end{abstract}

\section{A. INTRODUCTION}

Servier $^{1}$ is the second General Court's judgment on reverse payment settlements, which is among the most interesting current legal issues in the pharmaceutical sector. Following Lundbeck, ${ }^{2}$ the Servier judgment declared that generally these settlements had as their object the restriction, prevention of distortion of competition and were therefore forbidden under Article 101 Treaty on the Functioning of the European Union (hereafter, 'Article 101'). ${ }^{3}$ This commentary argues that such a broad general rule in Lundbeck is essentially unfair for undertakings and also non-optimal from the perspective of consumer welfare, which is a guiding principle of competition law that 'encourages markets to produce output as high as is consistent with sustainable competition, and prices that are accordingly as low' 4 and therefore implies a redistribution of wealth from producers to consumers. ${ }^{5}$ In the longer term, consumer welfare also includes innovation.

* LL.M. and PhD Candidate (University of Edinburgh), Bachelor of Law (Pontificia Universidad Católica de Valparaíso). The author may be contacted at: richard.tepper@ed.ac.uk. I am grateful to James Lee, Andrew McLean, and Joyman Lee for their editorial support. All errors and omissions are entirely my own.

${ }^{1}$ Case T-691/14 Servier and Others v European Commission [2018] ECLI:EU:T:2018:922.

${ }^{2}$ Case T-472/13 H. Lundbeck A/S and Lundbeck Ltd v European Commission [2016] ECLI:EU:T:2016:449.

${ }^{3}$ Article 101 prohibits agreements between undertakings, decisions by associations of undertakings and concerted practices that may affect trade between Member States and which have as their object or effect the prevention, restriction or distortion of competition within the internal market.

${ }^{4}$ Herbert Hovenkamp, 'Is Antitrust's Consumer Welfare Principle Imperiled? (2019) Journal of Corporation Law (Forthcoming); University of Pennsylvania, Institute for Law and Economics Research Paper No. 18-15, 3 $<$ https://ssrn.com/abstract=3197329> accessed 29 August 2019.

5 ibid. 
Servier is also novel in several respects. The General Court refined its approach by introducing an exemption for licensing agreements. It is submitted that such an exemption to Lundbeck's general rule is logically consistent with the underlying principles under Article 101.

Finally, this commentary explores the General Court's reasoning on the definition of the relevant market for the assessment of dominance in the context of Article 102 Treaty on the Functioning of the European Union (hereafter, 'Article 102'). ${ }^{6}$ The tribunal annulled the decision of the European Commission (hereafter, 'Commission') on the existence of an abuse of dominance based on criteria derived from previous case law rather than on a new analytical framework.

The commentary is structured as follows. Section A reviews the legal background on reverse payment settlements in the pharmaceutical sector. Section B summarises the facts of the case. Section C explains the main points of the Servier decision. Sections D and E comment on the application of Article 101(1) and the definition of the relevant market for the application of Article 102 respectively. Section F concludes.

\section{B. REVERSE PAYMENT SETTLEMENTS: PHARMACEUTICAL SECTOR}

The Commission adopted and published its final report of the Competition Inquiry into the Pharmaceutical Sector in 2009 (hereafter, 'Inquiry'). ${ }^{7}$ The Inquiry focused on the competitive relationship between originators and generic companies and the positive effects of competition brought by the market entry of generics on access to affordable medicine and public expenditures. ${ }^{8}$

In particular, the Commission indicated a special concern on firms' behaviours that may prevent or delay the entry of generic products into the market. The Inquiry identified that patent settlement agreements between originator companies and generic undertakings were one of several methods to extend the commercial life of the former's products and delay the market entry of generics.

This does not mean that all patent settlement agreements are inherently anticompetitive. Depending on the contractual provisions, the agreements may be anticompetitive at different levels or even not anticompetitive at all. Recognising this, the Commission distinguished anticompetitive

\footnotetext{
${ }^{6}$ Article 102 prohibits the abuse of a dominant position by one or more undertakings within the internal market or in a substantial part of it in so far as it may affect trade between Member States.

${ }^{7}$ Commission, 'Executive Summary of the Pharmaceutical Sector Report Inquiry Report' (Communication) (2009) ('Inquiry').

8 ibid 1-3.
} 
and non-anticompetitive patent settlement agreements based on two criteria: whether they limited ability of the generic company to enter the market (hereafter, 'market entry criteria') and whether they involved any type of value transfer from the originator to the generic firm (hereafter, 'value transfer criteria'). ${ }^{9}$

The market entry criteria gave place to the following categories: A-type agreements that allowed the generic to enter (or not to leave) the market and compete freely in it; and B-type agreements that limited the generic company's ability to enter and compete freely. ${ }^{10}$ This group included not only cases in which entry was not possible, but also instances in which entry was controlled to some extent by the originator company. For instance, the grant of a licence, ${ }^{11}$ agreement in which the generic company agreed to become a distributor of the originator, or arrangement to acquire the active ingredient of the medicine from the originator were also included in this category.

The value transfer criteria further divided B-type agreements into two sub-categories. If there was no value transfer, then it was a B.I. agreement. Conversely, if there was a value transfer, it was classified as a B.II. agreement.

The group of agreements that the Commission identified in the B.II. subcategory is commonly known as 'reverse payment settlements' because they involve an atypical direction of value transfer from the originator to the generic company. They are also called 'pay-for-delay' agreements because the generic undertaking usually commits to not challenge the validity of the patent, to end the litigation against the originator and to delay its market entry in return for a value transfer that does not necessarily have to consist of a monetary payment. Other names that can be found in the relevant literature are 'exclusion payments' 12 and 'exit payments'. ${ }^{13}$

\section{Controversy on the Nature of Reverse Payment Settlements}

\footnotetext{
${ }^{9}$ Commission, 'Pharmaceutical Sector Inquiry. Final Report' (Staff Working Document) (2009) paras. 741 -742.

${ }^{10}$ ibid.

11 Although the Commission considered the grant of a licence as a limitation to entry, the General Court in Servier created an exemption to the general rule for licencing agreements. The tribunal recognised there were some procompetitive effects of the licencing agreements in that context. See Servier v Commission (n 1), paras 954-955, 995.

${ }^{12}$ Herbert Hovenkamp, Mark D. Janis and Mark A. Lemley, 'Anticompetitive Settlement of Intellectual Property Disputes' (2003) 87 Minnesota Law Review 1719, footnote 130.

${ }^{13}$ For instance, Daniel A. Crane, 'Exit Payments in Settlement of Patent Infringement Lawsuits: Antitrust Rules and Economic Implications’ (2002) 54 Florida Law Review 747.
} 
Reverse payment settlements constitute an extrajudicial solution to disputes regarding the validity and scope of a patent. ${ }^{14}$ For proponents, the usage of such settlement agreements creates private benefits (reduced litigation costs and legal uncertainties for parties) and social benefits (reduced caseloads for courts). ${ }^{15}$ In addition, the possibility of entering into these agreements increase the incentive for both patent holders and generic undertakings to innovate. Given the higher degree of certainty that patents will not be infringed or found to be invalid, it adds value to the intellectual property rights of the patent holders. As for generic undertakings, the new financial resources gained from the settlement may increase the probability that they will 'invent around' the patent. ${ }^{16}$ This thus reflects the view that reverse payment settlements generally increase social welfare maximising wealth. ${ }^{17}$

On the other hand, reverse payment settlements are reached at the consumers' expense because generic entry provides them with a cheaper alternative. In fact, the agreement can be seen as a form of market-sharing, in which the incumbent firm shares its monopoly profits with the potential new entrant in order to preserve the monopoly. This reduces short-run consumer welfare, ${ }^{18}$ given that consumer surplus is less in a monopoly than in a duopoly. ${ }^{19}$ Consumers lose out because of the absence of price competition between settlers and potential competitors given that an allegedly invalid patent remained unchallenged. ${ }^{20}$ There is also a loss for society, particularly deadweight $\operatorname{loss}^{21}$, because of the temporary extension of the monopoly costs.

Finding the appropriate competition enforcement approach to these agreements would not be as difficult if the determination of the patent's validity and scope is an instantaneous and costless process. ${ }^{22}$ If a new product is within the scope of another valid patent, a settlement would not be

\footnotetext{
${ }^{14}$ Fabrizio Esposito and Francesco Montanario, 'A Fisftul of Euros: EU Competition Policy and Reverse Payments in the Pharmaceutical Industry’ (2014) 10 European Competition Journal 499, 502.

${ }^{15}$ Carl Shapiro, 'Antitrust Limits to Patent Settlements' (2003) 34 RAND Journal of Economics 391, 394; Crane (n 13) $757-59$.

${ }^{16}$ Crane (n 13) 762-65.

${ }^{17}$ Crane (n 13) 749.

${ }^{18}$ Leigh Hancher and Wolf Sauter, 'A Dose of Competition: EU Antitrust Law in the Pharmaceuticals Sector' (2016)

4 Journal of Antitrust Enforcement 381, 401.

${ }^{19}$ Shapiro (n 15) 395.

20 ibid 394.

21 There is a deadweight loss where economic resources are allocated inefficiently within the market. In the case of monopoly, this is derived from the reduction in output in which the monopolist incurs to increase the price of the product and maximise its profits. In such a situation, the society as a whole loses wealth because there are consumers that are able to buy the good at the competitive price but not at the monopolistic one.

${ }^{22}$ Crane (n 13) 754.
} 
problematic ${ }^{23}$ because it serves as an efficient way to protect a legally granted monopoly. However, if the new product falls outside the scope of existing patents, a settlement ought to be prohibited because the costs of monopoly are only socially tolerated in exchange for public disclosure of inventions which constitute an exception to the competition regime ${ }^{24}$. Given patent disputes involve complex legal issues and costly judicial proceedings, this creates the need for a legal rule that balances competing factors from providing incentives to innovate, promoting market competition and facilitating the appropriate use of reverse patent settlements. ${ }^{25}$

\section{Recent European Commission and US Enforcement Approach}

Since 2009, the Commission had adopted a more aggressive attitude towards reverse payment settlements. In 2013, it adopted the Lundbeck decision ${ }^{26}$ and considered agreements reached between Lundbeck and a group of generic companies on the antidepressant citalopram as restrictions by the object under Article 101. In 2014, it further adopted the Servier decision, ${ }^{27}$ holding the reverse payment settlements to patent disputes between Servier and its generic competitors on perindopril, a blood pressure medication, as restrictions by object under Article 101. However, the Commission's approach in Servier presented two novelties. ${ }^{28}$ First, although it maintained that these agreements were restrictive by object, it nevertheless examined their competitive effects. Second, it determined there was not only a breach of Article 101, but Servier's settlement strategy also constituted an abuse of dominant position under Article 102.

The Commission's Lundbeck decision was object of an action of annulment under Article 263 TFEU, which states that the Court of Justice of the European Union shall review the legality of acts of the Commission. The Court of Justice of the European Union includes both the General Court and the Court of Justice. The General Court has jurisdiction to hear and determine at first instance the action of Article $263^{29}$ and its decision may be subject to an appeal on a point of law

\footnotetext{
${ }^{23}$ Esposito and Montanaro (n 14) 502.

${ }^{24}$ Crane (n 13) 753-754.

${ }^{25}$ Crane (n 13) 748.

${ }^{26}$ Lundbeck (Case AT.39226) Commission Decision C80/13 [2013] 2015/C 80/07.

${ }^{27}$ Perindopril (Servier) (Case AT. 39612) Commission Decision C393/7 [2014] 2016/C 393/05.

28 These are noticed by Damien Geradin, Douglas Ginsburg and Graham Safty, 'Reverse Payment Patent Settlements in the European Union and the United States' (2015) George Mason University Legal Studies Research Paper Series LS 15-22, George Mason University Law \& Economics Research Paper Series 15-38, 22-23 <http://ssrn.com/abstract=2662575> accessed 1 April 2019.

${ }^{29}$ Article 256(1) Treaty of Functioning of the European Union.
} 
before the Court of Justice. ${ }^{30}$ The General Court's judgment, ${ }^{31}$ delivered in September 2016, was the direct antecedent for Servier. In it, the tribunal confirmed the approach taken by the Commission, determining that the agreements between Lundbeck and the generic companies had an anti-competitive object, and therefore was in breach of Article 101.

In contrast, the effect-based approach taken by the Supreme Court of the United States fuelled academic discussion on reverse payment settlements. In general, it can be said that competition rules are open-textured. They use a broad language that makes their scope to depend much on the attitude of the agencies and courts in their interpretation. In this sense, the literature distinguishes between a formalistic and an effects-based approach. ${ }^{32}$ The former, extensively used in the United States in the period between the 1950s-1970s and in the European Union until the end of the 1990s, applies competition rules based on the type of behaviour, creating presumptions of competitive harm for some categories of conduct. The latter focuses on outcomes instead, assessing on a case-by-case basis the competitive effect of the undertakings' practices. FTC $v$. Actavis Inc. ${ }^{33}$ the majority adopted a rule of reason approach against a minority in favour of the 'scope of the patent test'. This means that US courts must engage in a case-by-case analysis of the positive and negative effects of these agreements in order to assess if they constitute an 'unreasonable' restraint of trade that violates Section 1 of the Sherman Act. ${ }^{34}$ In this evaluation, the courts will bear in mind particularly the reverse payment's "[s]ize, its scale in relation to the payor's anticipated future litigation costs, its independence from other services for which it might represent payment, and the lack of any other convincing justification." ${ }^{{ }^{35}}$

\section{SERVIER'S FACTUAL BACKGROUND}

The primary patent of perindopril, a drug used for the treatment of hypertension developed by Servier, was due to expire in 2001. However, the primary patent was extended subsequently in several member states. In addition, Servier was the owner of several secondary patents related to

\footnotetext{
${ }^{30}$ ibid.

${ }^{31}$ Lundbeck (n 2).

${ }^{32}$ See Alison Jones, 'The journey toward an effects-based approach under Article 101 TFEU-The case of hardcore restraints' (2010) 55 Antitrust Bulletin 783, 785-793.

${ }^{33} 570$ U.S. _ (2013).

${ }^{34}$ The Section 1 of the Sherman Act is the main provision against anticompetitive agreements in the antitrust law of the United States. It declares illegal 'every contract, combination in the form of trust or otherwise, or conspiracy, in restraint of trade or commerce among the several States, or with foreign nations'. Courts have systematically interpreted that Section 1 only prohibits restraints of trade that are unreasonable.

35 ibid.
} 
the process of fabrication of the drug and obtained a patent for the second-generation perindopril in 2004.

Generic companies interested in producing perindopril challenged some of these patents through proceedings before the European Patent Office and the national courts. Servier and generic companies settled their patent disputes in 2005, 2006 and 2007 respectively, with settlement agreements containing non-marketing and non-challenge clauses as well as reverse value transfers from Servier to the generic undertakings.

In 2014, the Commission adopted the Servier decision ${ }^{36}$ that considered such agreements as restriction by objects in breach of Article 101 and Servier's settlement strategy as an abuse of dominance under Article 102. The decision led to several actions of annulment which resulted in eight judgments ${ }^{37}$ by the General Court delivered in December 2018.

\section{THE SER VIER JUDGMENT ${ }^{38}$}

The judgment by the General Court, although generally following the line previously taken in Lundbeck, presents some novelties. The three main principles are: first, Lundbeck is not an exception and the General Court will generally respect the Commission's approach in finding reverse payment settlements restrictions by object under Article 101 (unless the Court of Justice overrules on the issue); second, the tribunal in some instances is willing to declare licensing agreements exempted from that general rule, and therefore categorize as restrictions by effects; and third, the Commission must exercise caution in defining the relevant market and assessing market power under Article 102, especially when market characteristics make the hypothetical monopolist test unsuitable. Each of these is addressed in turn below.

\section{Upholding Lundbeck's General Rule: Article 101 Restrictions by Object}

Regarding the first principle, for most of the agreements between Servier and the generic companies, the General Court found that they constituted restrictions by object under Article 101 following the Lundbeck's criteria. In its reasoning, the tribunal set forth three requirements to hold an agreement as preventing, restricting or distorting competition by its very nature. ${ }^{39}$ First, the

\footnotetext{
${ }^{36}$ Perindopril (Servier) (n 27).

${ }^{37}$ The other judgments are T-677/14 Biogaran $v$ Commission, T-679/14 Teva UK and Others $v$ Commission, T-680/14 Lupin v Commission, T-682/14 Mylan Laboratories and Mylan v Commission, T-684/14 Krka v Commission, T701/14 Niche Generics v Commission and T-705/14 Unichem Laboratories $v$ Commission.

${ }^{38}$ Servier's General Court Judgment (n 1).

${ }^{39}$ Straus deduced a similar group of requirements in the Commission's decision on Servier, while Yagci and Cheah construed in a comparable manner the Lundbeck judgment by the General Court. See Joseph Straus, 'Can Antitrust
} 
relationship between the originator and the generic company must be, at least, one of potential competition. ${ }^{40}$ Second, the generic undertaking must commit itself to limit its independent efforts to enter the market. ${ }^{41}$ Third, there must be a significant inducement from the originator to the generic company. ${ }^{42}$

While the first requirement is necessary for an agreement to fall under the scope of Article 101, the second and third requirements are emblematic of the novel approach taken by the General Court towards reverse patent settlements. Although the tribunal accepted non-marketing and nonchallenge clauses might be legitimate for the resolution of some patent disputes, this was only so when they were based on the recognition of the patent's validity since the clauses simply replicated the effects of patent protection rather than created new competitive restrictions. ${ }^{43}$

On the other hand, the settlement agreement becomes problematic when it is not based on the recognition of the patent's validity by the generic company. Furthermore, the introduction of a reverse payment increases the suspicious character of the agreement from a competition law perspective. According to the General Court, if the patent settlement contained a significant incentive, this should be considered as the true cause of the competitive restrictions introduced by the non-marketing and non-challenge clauses. ${ }^{44}$ To be considered as a significant incentive and thus an inducement by the originator company to buy additional time, the payment must be disproportionate to the costs that are objectively necessary for the resolution of the patent dispute in light of its complexity. ${ }^{45}$ Such methods of resolving patent disputes affect not only competition but also the public interest in providing widespread access to medicines at the lowest possible cost.

\section{Servier's Exemption for Licensing Agreements: Article 101 Effects Analysis}

The General Court in Servier went one step further by recognising an exemption for licensing agreements regarding the agreements between Servier and Krka, another pharmaceutical

Adequately Assess Patent Settlement Agreements Disconnected from Patent Law Relevant Facts? The Servier Case - Its Public Perception and Its Underlying Facts' (2016) 38(9) European Intellectual Property Review 533, 540; Melih Yagci and Jonathan Yit Cheng Cheah, 'Should Reverse Payment Settlements Be Subject to Competition Law Scrutiny? - A Discussion on the Economics and the Anti-Competitive Effects of Pharmaceutical Patent Settlements' (2018) 39(7) European Competition Law Review 306, 312.

${ }^{40}$ See assessment of the existence of potential competition in Servier (n 1) paras 316-86.

41 ibid para 272.

42 ibid.

43 ibid paras 258-62.

44 ibid paras 272-74.

45 ibid paras 277-80. 
undertaking. ${ }^{46}$ To understand such a determination, it is important to notice that their relationship includes not only a settlement agreement but also a licensing agreement for the production and commercialization of one of the newest Servier's patents in seven member states. Krka, in exchange for that licence, was to pay a royalty of 3 percent on its net sale prices even though Servier did not exclude the possibility of using that patent itself in those countries. The court found that the contractual framework formed by the settlement and the licensing agreements did not reveal the degree of harm needed to qualify them as restrictions by object under Article 101.

The tribunal justified such a conclusion with six different arguments. First, it claimed that a licensing agreement was particularly appropriate to settle a patent dispute because it satisfied the interests of both parties. On one hand, it protected the patent which was in the interest of the originator company. On the other hand, it authorized the entry of a generic drug to the market as desired by the competitor. ${ }^{47}$ This explicitly contradicted the Commission's position in the Inquiry, where it declared that the grant of a licence was a restriction of market entry because it restricted the generic undertaking to compete on the originator's terms. ${ }^{48}$

Second, a licensing agreement made sense for the licensee only if the licence was actually used. ${ }^{49}$ In other words, the only rational objective such a contract may have was for the licensee to effectively enter the market.

Third, the General Court claimed at the core of its reasoning that a licensing agreement was based on the recognition of a patent's validity and thus supported the legitimacy of the settlement agreement. ${ }^{50}$ Both agreements were seen as shaping a unitary contractual framework and therefore should be jointly assessed. Since one provided a competitive justification for another, it was concluded that they did not show the natural degree of harm necessary to categorize as a restriction by object.

Fourth, and related to the previous point, the licensing agreement mitigated the effects of competitive restrictions within the settlement. The non-marketing clause was neutralized since the licence agreement encouraged the market entry of the generic company. ${ }^{51}$ The non-challenge

\footnotetext{
${ }^{46}$ Regarding the agreements between Servier and Krka, see also Case T-684/14 Krka Tovarna Zdravil v Commission [2018] ECLI:EU:T:2018:918.

${ }^{47}$ Servier's General Court Judgment (n 1) paras 944-45.

${ }^{48}$ Commission, Staff Working Document (n 9) 269.

${ }^{49}$ Servier (n 1) para. 947.

50 ibid paras $943 \mathrm{ff}$.

51 ibid para 954.
} 
clause was also diminished in its effect because it permitted market entry without the risk of costly litigation. $^{52}$

Fifth, inducement was less evident in the context of a licensing agreement than in other cases. Such a method to settle patent disputes involved a financial transfer from the generic undertaking to the originator rather than in reverse. Therefore, there would be inducement only if the royalty paid in exchange for the licence was so abnormally low that it could not be explained purely on the basis of the economic value of the object of the contract. ${ }^{53}$ Similar to the requirement that the Commission had to prove inducement in other contexts, it was also for the Commission to prove this abnormality, which it failed to do in this instance. ${ }^{54}$

Lastly, the General Court argued that its conclusion did not contradict existing case law nor Regulation 772/2004 on the application of Article 101(3) to technology transfer agreements ${ }^{55}$ (hereafter, 'Regulation'). In the former case, it interpreted Windsurfing International ${ }^{56}$ and Bayer and Maschinenfabrik Hennecke ${ }^{57}$ as judicial recognition that not all patent settlement agreements containing a non-challenge clause ran afoul of Article 101(1). In the latter case, Article 2 of the Regulation declares that Article 101(1) shall not apply to technology transfer agreements entered into between two undertakings permitting the production of contract products. However, Article $5(1)(c)$ determines that this exemption does not apply to 'any direct or indirect obligation on the licensee not to challenge the validity of intellectual property rights which the licensor holds in the common market'. The General Court concluded that while a non-challenge clause of a licensing agreement was an excluded restriction from the exemption provided by Article 2 of the Regulation,

\footnotetext{
52 ibid para 955.

53 ibid paras 949-52.

54 ibid para 981.

55 The Regulation defined in its Article 1(1)(b) technology transfer agreement as 'a patent licensing agreement, a know-how licensing agreement, a software copyright licensing agreement or a mixed patent, know-how or software copyright licensing agreement, including any such agreement containing provisions which relate to the sale and purchase of products or which relate to the licensing of other intellectual property rights or the assignment of intellectual property rights, provided that those provisions do not constitute the primary object of the agreement and are directly related to the production of the contract products; assignments of patents, know-how, software copyright or a combination thereof where part of the risk associated with the exploitation of the technology remains with the assignor, in particular where the sum payable in consideration of the assignment is dependent on the turnover obtained by the assignee in respect of products produced with the assigned technology, the quantity of such products produced or the number of operations carried out employing the technology, shall also be deemed to be technology transfer agreements'.

${ }^{56}$ Case 193/83 Windsurfing International Inc. v Commission [1986] ECLI:EU:C:1986:75.

${ }^{57}$ Case 65/86 Bayer AG and Maschinenfabrik Hennecke GmbH v Heinz Süllhöfer [1988] ECLI:EU:C:1988:448.
} 
such applied only in so far as the agreements contained restrictions that fell within the scope of Article 101(1).

Since the tribunal did not consider the contractual framework between Servier and Krka a restriction by object, it proceeded to analyse the effects of the agreements. ${ }^{58}$ Although the Commission's decision was novel in engaging in an effects analysis of the agreements, the tribunal ultimately found that the Commission failed to prove anticompetitive effects of the patent settlements. In particular, it criticised the Commission's approach as being based more on hypothetical effects rather than actual market developments after the undertakings entered into the relevant agreements.

\section{Market Definition in the Pharmaceutical Sector: Article 102 Analysis}

Finally, the General Court annulled the Commission's decision regarding Servier's settlement strategy as an abuse of a dominant position under Article 102. In a rare occasion, the tribunal found that the Commission erred in its analysis of market definition in the pharmaceutical sector, meaning that the grounds for finding Servier a dominant undertaking were flawed. This reminds of the key role of market definition in Article 102 cases. In order to decide if the undertaking's behaviour constitutes an abuse of a dominant position, the first analytical step is to determine if the firm is dominant. ${ }^{59}$ For such a task, a relevant market must be defined in order to assess the competitive constraints that affect the undertaking. If these constraints are strong enough, the firm is found non-dominant and the analysis ends there. The General Court's decision in this case means that, for now, there will be no judicial guidance on the relationship between pay-for-delay agreements and possible abuses of dominance by originator companies under EU competition law.

\section{E. COMMENTS ON THE APPLICATION OF ARTICLE 101(1)}

The article now turns to analyse affirmation of Lundbeck's general rule, the exemption for licensing agreements recognised in Servier, and lastly the definition of relevant market in the pharmaceutical sector.

\section{Criticism of Lundbeck's General Rule}

\footnotetext{
${ }^{58}$ See the conclusions of the tribunal on the effects of the agreements in Servier (n 1) paras 1075-1234.

59 A dominant position is 'a position of economic strength enjoyed by an undertaking which enables it to prevent effective competition being maintained on the relevant market by giving it the power to behave to an appreciable extent independently of its competitors, customers and ultimately of its consumers'. Case 27/76, United Brands v. Commission [1978] ECR 207, para. 126.
} 
Before Servier, the treatment of reverse payment settlements was not a settled issue and some commentators have argued that the approach taken by the General Court and the Commission in Lundbeck is too harsh. ${ }^{60}$ These positions are augmented by the position adopted by the US Supreme Court in Actavis, declaring that these agreements must be assessed under a rule of reason approach. $^{61}$

It must first be recognized that classifying these agreements as restrictions by object under Article 101 is not without reason. On the contrary, it is fair to say that they resemble the type of agreements that have been previously classified as restrictions by object by the European courts. ${ }^{62}$ A pay-for-delay agreement explicitly provides that one undertaking must delay its market entry, while the other undertaking compensates for the potential loss in revenue through a transfer of value. In this sense, the restriction is similar to the one found in the BIDS case, ${ }^{63}$ in which a competitor was compensated for leaving the market rather than not staying in. The Court of Justice found that there was a restriction by object in BIDS, arguing that:

The BIDS arrangements are intended therefore, essentially, to enable several undertakings to implement a common policy which has as its object the encouragement of some of them to withdraw from the market and the reduction, as a consequence, of the overcapacity which affects their profitability by preventing them from achieving economies of scale. ${ }^{64}$ And that:

That type of arrangement conflicts patently with the concept inherent in the EC Treaty provisions relating to competition, according to which each economic operator must determine independently the policy which it indents to adopt on the common market. Article 81(1) EC is intended to prohibit any form of coordination which deliberately substitutes practical cooperation between undertakings for the risks of competition. ${ }^{65}$

\footnotetext{
${ }^{60}$ See Straus (n 39); Yagci and Cheah (n 39); Vilhelm Schröder, 'Pay-For-Delay Settlements in the EU: Did the Commission Go Too Far?' (2016) 37(12) E.C.L.R. 506; Batchelor and others, 'Lundbeck Raises More Questions Than Answers on "Pay-For-Delay" Settlements; Creates Damaging Divergence from US Law' (2017) 38(1) E.C.L.R. 3.

${ }^{61}$ However, the Court did not contribute much in explaining how this rule must be applied. Geradin, Ginsburg and Safty identified four problems that must be addressed by lower courts: i) what is a reverse-payment?; ii) when is a reverse-payment "large and unjustified"?; iii) how will courts evaluate the procompetitive effects of a reverse-payment settlement agreement?; and iv) what is the role of the FTC in regulating reverse-payment settlement agreements?; See Geradin, Ginsburg and Safty (n 28) 6-16.

${ }^{62}$ Schröder (n 61) 508.

${ }^{63}$ Case C-209/07 Competition Authority v Beef Industry Development Society Ltd and Barry Brothers (Carrigmore) Meats Ltd. [2008] ECLI:EU:C:2008:643.

${ }^{64}$ ibid para 33.

${ }^{65}$ ibid para 34.
} 
There are however differences between the BIDS case and the current case since the former concerns actual competitors while the latter concerns potential competitors according to the Commission and the General Court. This finding has been previously criticized ${ }^{66}$ as the tribunal was effectively protecting unlawful competition. Nevertheless, there is no clear answer on this matter. The tribunal was right in observing that there were several different lawful ways of entering the market and the undertakings in both Lundbeck and Servier had already undertaken some of the necessary steps. Even though patents are presumptively valid, they are merely probabilistic property rights since they do not guarantee success in patent litigation; thus the legal protections are less strong than what is usually assumed ${ }^{67}$ It is for the court to determine what probability is sufficient in each case as potential competition requires more than the theoretical ability to enter the market.

A second point is that, from a distributive perspective, such agreements affect consumer welfare in the short-term because the output of the product is limited and the price is kept at a monopolistic level for an additional period. Through the settlement, the originator company extends the amount of time in which it extracts monopoly rents ${ }^{68}$ through the exclusion of its generic competitors. From this point of view, it makes sense that the General Court in Lundbeck highlighted reverse payments are related to the profits the entrants would have obtained had they enter into the market. ${ }^{69}$ Nonetheless, consumer welfare has a special structure in these cases: the main affected buyers by the extension of monopoly are the social security systems of the member states instead of the end consumers. ${ }^{70}$ Although this introduces an atypical element in the consumer welfare objective, it also adds special political significance to it.

Considering the content of the agreements, their similarities with the BIDS case, the finding of potential competition, and the impact on short-term consumer welfare, it could be argued that such agreements indeed have as their object to prevent, restrict or distort competition.

Notwithstanding, there are also strong reasons to believe that this characterisation is unfair and non-optimal. It is submitted that the content of the contractual provisions, their objectives, and the economic and legal context of which they form a part does not justify characterising them as

\footnotetext{
${ }^{66}$ For instance, Schröder (n 61) 507-508; Batchelor and others (n 61) 4.

${ }^{67}$ Shapiro (n 15) 395.

${ }^{68}$ Monopoly rents are those benefits obtained by the monopolist due to the higher price at which it sells the product.

${ }^{69}$ Lundbeck's General Court Judgment (n 2) para 354.

${ }^{70}$ The Commission was especially concerned about public budgets in the Inquiry. See Commission, Inquiry (n 7) 23.
} 
restrictions by object. In both Lundbeck and Servier, the General Court argues that when the patent settlement agreement contains a significant reverse payment, the court will construe the agreement as based on this inducement rather than on the patent's validity; thus restrictions by object because the originator is 'buying off' competition. ${ }^{71}$ However, this is not necessarily true.

In general, the direction of the payment and its size are related to the expected profits gained from the generic entry. ${ }^{72}$ Although how strong the parties believe that the patent plays a role in the negotiation, broader factors regarding uncertainty about the outcome and the bargaining power of the undertakings cannot be ignored. The level of uncertainty, which is not solely determined by the strength of the patent, can drive the originator to pay for a settlement especially when profits at risk are significant. ${ }^{73}$ For instance, the originator would confront an immediate fall of prices and declarations of invalidity in other relevant markets in the event of a negative outcome. ${ }^{74}$ The bargaining power of respective firms, which is related to factors such as their relationship, financial strength, and risk appetites, ${ }^{75}$ also influences the outcome of the negotiation. Since most of these factors are not directly related to the possible anticompetitive effects of the settlement, analysis based only on the existence and reverse direction of the payment is insufficient to make a final conclusion. This makes the Lundbeck rule, followed in Servier, essentially unfair to undertakings, which could then be punished even if the agreement is not anticompetitive.

Moreover, it is a mistake to automatically assume there will be impacts on short-term and long-term consumer welfare. First, if the patent is valid and the generic product is intended to be marketed within its scope, the agreement is not extending the period in which the inventor obtains monopoly rents and would only have a neutral effect. Furthermore, such an effect can be positive if the agreement authorizes market entry before the expiration of the patent. Second, Lundbeck's prohibition of patent settlement agreements as restriction by object diminishes the level of protection for the inventor and could result in a sub-optimal level of investment in innovation. In fact, it is particularly worrying that the apparent consequence of the General Court's approach is that every case where the validity of a patent is in doubt must be taken to final judgment. ${ }^{76}$ This is

\footnotetext{
${ }^{71}$ Servier (n 1) paras 264-272; Lundbeck’s General Court Judgment (n 2) paras. 352-355.

72 William Choi, Bruce Den Uyl, and Mat Hughes, 'Pay-For-Delay Practices in the Pharmaceutical Sector: Lundbeck, Actavis, and Others' (2014) 5 J.E.C.L. \& Pract. 44, 47.

${ }^{73}$ Crane (n 13) 772.

74 Patrick Actis Perinetto, 'The Complexities of EU Competition Law Assessment of Pharmaceutical Pay-For-Delay Agreements' (2018) 39(2) E.C.L.R. 70, 74.

75 ibid 774-75.

${ }^{76}$ Batchelor and others (n 61) 7.
} 
relevant since the Inquiry showed that the level of innovation had already declined in the pharmaceutical sector. $^{77}$

There is an additional argument that shifts the balance towards an effect-based approach. In Cartes Bancaires, ${ }^{78}$ the European Court of Justice stressed that restrictions by object must be interpreted restrictively, because:

The concept of restriction of competition 'by object' can be applied only to certain types of coordination between undertakings which reveal a sufficient degree of harm to competition that it may be found that there is no need to examine their effects, otherwise the Commission would be exempted from the obligation to prove the actual effects on the market of agreements which are in no way established to be, by their very nature, harmful to the proper functioning of normal competition. ${ }^{79}$

Given the growing criticism against the current approach on reverse payment settlements, a more appropriate approach would be to consider them restrictions by effect under Article 101 and to assess their consequences on competition case by case.

\section{Criticism of Servier's Exemption for Licensing Agreements}

It must first be recognized that the General Court's approach is at least logically consistent with the introduction of an exemption for Servier and Krka's licensing agreement. Given Lundbeck's general rule is conditioned upon settlement agreements not being based on the validity of the patent, Servier's licensing agreement with Krka was exempted precisely because it was. Providing such an exemption mitigates the concerns of unfairness and non-optimality created by Lundbeck's general rule. Nevertheless, there are still some unresolved issues.

The first issue is that licensing agreements can also have anticompetitive potential. When they are agreed between horizontal competitors, they could give the patent holder control over the generic undertaking's output and price. ${ }^{80}$ Because reverse patent settlements may be either anticompetitive or procompetitive depending on the circumstances, the General Court adopted the correct approach to assess them by their actual effects rather than deeming them as inherently legal or illegal.

\footnotetext{
${ }^{77}$ Commission, Inquiry (n 7) 3.

${ }^{78}$ Case C-67/13 P. Groupement des Cartes Bancaires (CB) v European Commission [2014] ECLI:EU:C:2014:2204.

${ }^{79}$ ibid para 58.

${ }^{80}$ Crane (n 13) 765-66.
} 
A second issue is the General Court's criteria to determine exemptions. To explain why this may be problematic, it is necessary to first explore the scope of the patent test. Explicitly rejected by the General Court ${ }^{81}$ and also rejected by the Supreme Court of the United States in Actavis, ${ }^{82}$ the scope of the patent test proposes for courts to accept the exclusion of competitors so long as the restrictions are within the scope of the rights of the patent holder. In other words, it proposes an assessment of the validity and scope of the patent to determine if the settlement agreement can be considered as an exercise of intellectual property rights and therefore exempted from competition rules.

There are good reasons to reject this test in the European Union. First, it would go against settled case law that states the exercise of intellectual property rights is subject to Articles 101 and $102 .{ }^{83}$ Second, such a conclusion is necessary to harmonize the distribution of competences in intellectual property issues, which are taken by national courts. For the Commission and the General Court to accept the scope of the patent test would go against the principles of consistency and certainty essential in a legal system. It is suggested that, unless there are a considerable number of national decisions against the validity of a patent, the Commission and the General Court should be cautious and resort to the presumption of validity that patents have. ${ }^{84}$

It is clear that it would not be sensible to apply the scope of the patent test in the European Union, especially because of its institutional arrangements in intellectual property issues. Notwithstanding, the General Court adopted an alternative approach which in fact is harder to grasp. While the scope of the patent test assesses if the restriction can be construed as an exercise of intellectual property rights, the current approach evaluates whether the agreements are based on the parties' recognition of the validity of the patent (and not whether they are effectively valid or not). In general, it is presumed that when a reverse payment is introduced, the agreement is not based on such recognition. This presumption is not necessarily true because while parties may recognize that the patent is valid, they understand ultimately that protracted litigation introduces potential risks and unpredictabilities. It is also not clear if the tribunal is looking at either the parties' intentions or for more abstract considerations involving the objectives of the agreements.

\footnotetext{
${ }^{81}$ Lundbeck's General Court Judgment (n 2) paras 478-516.

${ }^{82}$ See, particularly, the dissenting opinion by Chief Justice Roberts. There, Chief Justice Roberts supported the scope of the patent test.

${ }^{83}$ Windsurfing International (n 57) paras 26, 92.

${ }^{84}$ Schröder (n 61) 512.
} 
This uncertainty over the rationale of the exemption impedes its applicability and potential extension in the future.

\section{F. COMMENTS ON THE DEFINITION OF THE RELEVANT MARKET}

Another novelty of the Commission's decision is finding Servier to have abused its dominant position in the perindopril market. The General Court, however, annulled this part of the decision by holding the Commission erred in the definition of the relevant market, and thus in the finding of dominance.

The general principles regarding economic appraisals in competition law can be found in case law. ${ }^{85}$ The general rule is that the Community judicature exerts a comprehensive review of the application of competition rules. However, economic appraisals are subject only to limited review. This means that the Court can only check if the decision complies with the relevant rules on procedure, complies with the rules on stating reasons, accurately states the facts, or is the result of any manifest error of assessment or misuse of powers. In any case, the tribunal cannot substitute its own assessment of matters of fact for the Commission's. This does not mean that the Community judicature is prohibited to review the Commission's interpretation of economic data (and therefore, the definition of relevant market). On the contrary, the Court must:

Not only establish whether the evidence put forward is factually accurate, reliable and consistent but must also determine whether that evidence contains all the relevant data that must be taken into consideration in appraising a complex situation and whether it is capable of substantiating the conclusions drawn from it. ${ }^{86}$

Given Lundbeck does not concern a breach of Article 102, it does not provide judicial guidance on defining the relevant market in the pharmaceutical sector. Fortunately, the first instance judgment of AstraZeneca v European Commission of the General Court serves as a good illustration of how the courts would approach market definition in the sector ${ }^{87}$ with its unique characteristics and particular conditions of demand and supply that affect competitive constraints.

Taking AstraZeneca and Servier together, it is possible to see that the General Court took into account the market particularities of pharmaceutical drugs summarized in three different, but

\footnotetext{
${ }^{85}$ See Case T-201/04 Microsoft v Commission [2007] ECLI:EU:T:2007:289, paras 87-89; Servier (n 1) paras 13721379.

${ }^{86}$ Microsoft (n 86) para 89.

${ }^{87}$ Case T-321/05 AstraZeneca AB and AstraZeneca plc v European Commission [2010] ECLI:EU:T:2010:266.
} 
related points. ${ }^{88}$ First, the pharmaceutical markets are different than normal markets because of the influence of administrative regulations and reimbursement policies of social security systems in different member states. Second, it is the medical doctors who determine what products to buy and not the final consumers (the end-patients). Third, doctors are not as sensitive to prices as consumers do, since their decisions are more guided by the therapeutic use of the medicine. As a consequence, the therapeutic aspects of different drugs may create important competitive constraints.

These characteristics shape both the process of defining a relevant market by the Commission and that of reviewing such a definition by the tribunal. In essence, the market particularities of pharmaceutical drugs show a decreased relevance of prices in comparison to other markets. Because decisions are not taken purely on the basis of prices but more on therapeutic considerations, price competition is much less intense. Since there is not a clear correlation between price levels and the therapeutic effects of the drug, the price also loses its importance indirectly.

This does not mean that prices are not important at all in this sector. They may be relevant, for instance, through recommendations or incentives provided by the social security systems to prefer an alternative product. Nevertheless, it is fair to claim that price levels themselves do not provide an adequate understanding of the competitive constraints in the pharmaceutical markets. ${ }^{89}$

This conclusion radically changes the definition of the relevant market. The Commission Notice on the Definition of the Relevant Market (thereafter, 'Commission Notice') states that:

A relevant product market comprises all those products and/or services which are regarded as interchangeable or substitutable by the consumer, by reason of the products' characteristics, their prices, and their intended use. ${ }^{90}$

However, in practice, prices are much more important because the small but significant non-transitory increase in price test (hereafter, 'SSNIP test') is widely accepted as the main method to define a market. The SSNIP is a conceptual framework that defines the relevant market for competition cases as the smallest set of products and locations that could be hypothetically monopolised. The test assesses the candidate market by considering whether a small increase in

\footnotetext{
${ }^{88}$ Servier (n 1) paras 1385-1388; AstraZeneca (n 88) paras 158, 178, 183, and 187.

${ }^{89}$ Servier (n 1) para 1385; AstraZeneca (n 88) 187.

${ }^{90}$ Commission, 'Notice on the Definition of Relevant Market for the Purposes of Community Competition Law' OJ C 372 (1997) para 7.
} 
price (normally $5 \%$ ) by a hypothetical monopolist would be profitable. ${ }^{91}$ If such an increase would deviate demand to other products or locations to the extent that it is not profitable, this means that there are still some products out that are considered interchangeable by the consumers, and therefore the set must be expanded. The Commission Notice does not go as far as to consider it the principal method for delineating the market, but it affords the SSNIP test an important place. $^{92}$ Some scholars have argued that a definition of the relevant market based other than on the hypothetical monopolist test will not provide, except by chance, any meaningful indication of market power. ${ }^{93}$ But if prices do not guide competition in the pharmaceutical sector to the same extent as in other sectors, nor can they shape competitive constraints and thus market definition, it means that the hypothetical monopolist test loses much of its effectiveness in this context.

In Astrazeneca, the General Court examined the existence of gradual and asymmetric substitution of $\mathrm{H} 2$ antagonists (a type of medicine that blocks the action of histamine at the receptors in the stomach) by proton-pump inhibitors (hereafter, 'PPIs'). It determined that such a process could be analysed under the 'theoretical framework' of the Commission Notice and that it was insufficient to conclude that a competitive constraint existed. ${ }^{94}$ However, the General Court's analysis was incomplete. The tribunal avoided the issue about the hypothetical monopolist test in the pharmaceutical sector, claiming that:

Whatever the actual applicability of the theoretical approach (...) to pharmaceutical product markets, and without needing to adopt a position in this respect, the Court notes that the assertion that prescribing doctors and patients are not sensitive to relative price changes does not affect the validity of the view that, in principle, the gradual nature of the increase in sales of a new product substituting for an existing product is not sufficient to conclude that the existing product necessarily exercises a significant competitive constraint over the new one. ${ }^{95}$

Nonetheless, the tribunal seemed to provide a general principle on the relevance of prices in the pharmaceutical sector, stating that:

\footnotetext{
91 ibid paras 15-19.

92 ibid.

${ }^{93}$ Simon Bishop and Mike Walker, The Economics of EC Competition Law: Concepts, Application and Measurement (3rd edn, Sweet \& Maxwell 2010) 114.

${ }^{94}$ AstraZeneca (n 88) paras 87-91.

95 ibid para. 91.
} 
The specific features which characterise competitive mechanisms in the pharmaceutical sector do not negate the relevance of price-related factors in the assessment of competitive constraints, although those factors must be assessed in their specific context. In the pharmaceutical sector, competitive relationships respond to mechanisms which differ from those determining competitive interactions normally present in markets which are not so heavily regulated. ${ }^{96}$

In Servier, one of the arguments made against the Commission's decision was the excessive relevance given to prices when defining the relevant market and that it failed to take into account how atypical the sector was ${ }^{97}$. The General Court, although repeating the principle of Astrazeneca and asserting that the Commission had effectively taken into account multiple factors, held that the Commission erred because it deduced from the low price-elasticity of perindopril that the medicine was not subject to significant competitive constraints. ${ }^{98}$ The Court argued reliance on this economic data alone was insufficient to reach that conclusion because of the different dynamics of the pharmaceutical markets, and that competitive constraints can appear in other ways, particularly through innovation, product quality, and promotion. ${ }^{99}$

Given the relevance of prices must be confined within its proper context, and competitive constraints demonstrated through non-price parameters, it is necessary then to find another guiding principle for market definition in the pharmaceutical sector. It is suggested that such a guiding principle is the therapeutic use of the medicine that is complemented by other non-price factors.

\section{Non-Price Factor: Therapeutic Use}

Perindopril is in a category of medicines called angiotensin converting enzyme (ACE) inhibitors, which are used for the control of blood pressure. Given such, the dispute on market definition was determining whether to adopt a narrow (constituted only by perindopril) or broad (constituted by all the ACE inhibitors) definition of the relevant market.

The Commission stated that there could not be substitution among different ACE inhibitors because of their differences in efficacy, use and secondary effects. ${ }^{100}$ However, the General Court considered this finding to be erroneous. After responding to every one of the Commission's

\footnotetext{
96 ibid para. 183.

${ }^{97}$ Servier's General Court Judgment (n 1) paras. 1306-1318.

98 ibid paras. 1585, 1589-1590.

99 ibid para. 1578.

100 ibid para. 1419.
} 
arguments in the matter, the tribunal determined that the ACE inhibitors were not a heterogeneous group of products. On the contrary, they were indistinguishable from each other and were mutually substitutable from a therapeutic perspective. ${ }^{101}$ This made them form part of the same relevant market. As was previously mentioned, the Commission Notice on the definition of the relevant market defined the product market as that which comprised all the products which were 'interchangeable or substitutable by the consumer'. ${ }^{102}$ In the case of medicines, the possibilities of substitution emerged when the therapeutic uses were equivalent.

The core focus on the therapeutic use of a pharmaceutical product underlines the General Court's reasoning in both AstraZeneca and Servier notwithstanding their differing outcomes. While in Servier, the General Court found that the group of ACE inhibitors was equivalent from the perspective of therapeutic use; in AstraZeneca, it determined that there was a continuum of treatments for acidity and that the particular medicine prescribed by doctors depended on the severity of the affliction. The tribunal observed that since PPIs were prescribed for the most serious cases and $\mathrm{H} 2$ antagonists were recommended only for mild conditions, $\mathrm{H} 2$ antagonists and PPIs had different therapeutic uses and were not interchangeable to provide competitive constraints. ${ }^{103}$

\section{Other Non-Price Factors: Inertia, Patient's Propensity, and Promotional Efforts}

Another non-price factor discussed in both cases is that of inertia that favour a narrow market definition. The Commission in Servier found that a high degree of inertia existed and was a product of doctors being cautious towards new products and their fears of secondary effects. In this sense, doctors' inertia could protect a pharmaceutical product from the competitive constraint posed by potential competition. However, the General Court concluded that the Commission failed to prove the existence of inertia in this case due to several factors. First, due to the homogeneity of the ACE inhibitors, there were no concerns over therapeutic uses that would limit doctors' choices in principle. ${ }^{104}$ Second, if inertia was present, the tribunal intuited that it would not be beneficial for Servier due to perindopril's existing customer base. ${ }^{105}$ Third, the Commission's prediction regarding the continual growth of perindopril among ACE inhibitors was relative since the medicine was not the most successful in the category. ${ }^{106}$ Fourth, significant fluctuations in the

\footnotetext{
101 ibid para. 1481.

102 Commission, Notice (n 91), para. 7.

${ }^{103}$ Astrazeneca (n 88) paras. 68-73.

104 Servier's General Court Judgment (n 1) para. 1489.

105 ibid para. 1495.

106 ibid paras. 1495-1500.
} 
relative sales of ACE inhibitors throughout the 2000s challenged the alleged existence of a high degree of inertia. ${ }^{107}$ Fifth, neither the studies presented by the firms nor the answers given by the undertakings to the Commission established the existence of a significant degree of inertia. ${ }^{108}$

The Commission also considered two other non-price factors that played a role in its definition of the relevant market. The first is the patients' propensity not to change their treatment. The Commission decided that, because in its view the ACE inhibitors were heterogeneous from a therapeutic perspective, patients would be unwilling to switch their medicines since the substitutes were associated with additional medical costs and health risks. ${ }^{109}$ The General Court held this conclusion to be erroneous because ACE inhibitors were homogeneous, and also due to some errors made by the Commission in assessing the available evidence. ${ }^{110}$

The second is promotional efforts. The Commission indicated that while promotional efforts, in theory, could intensify competition in the market, they were limited by doctors' inertia and patients' propensity not to switch treatments in this case. In its view, promotion efforts simply increased the existing preference of loyal prescribers. ${ }^{111}$ Having previously considered that none of these non-price limitations had been proved by the Commission, the General Court held in contrast that Servier's promotional efforts suggested perindopril was being effectively constrained. ${ }^{112}$

At this point, one can see why the Commission's decision was overturned. Both arguments on doctors' inertia and patients' propensity had been weakened or discarded by the General Court. Additionally, in a homogenous medicinal market to control blood pressure, promotional efforts make more sense from an economic perspective. This observation is corroborated by the levels of expenditures made by Servier in promotional efforts.

After due consideration of all relevant non-price factors, the General Court concluded that there were substitution possibilities between perindopril and other ACE inhibitors which exerted competitive constraints on the former. ${ }^{113}$ As a logical consequence, the narrow market definition adopted by the Commission to determine Servier was a dominant undertaking had to be discarded

\footnotetext{
107 ibid paras. 1501-1507.

108 ibid paras. 1508-1512.

109 ibid paras. 1514-1516.

110 ibid paras. 1519, 1540.

111 ibid para 1541.

112 ibid paras 1564-1565.

113 ibid paras 1589-1592.
} 
and the decision annulled. With no market dominance, there could not be an abuse of a dominant position under Article 102. Most importantly, the General Court did not introduce new elements in its assessment when defining the relevant market. Such a conclusion shows that, although the General Court's review on complex economic appraisals is limited, the Commission does not have free rein when defining markets. On the contrary, it must be careful when assessing available evidence and drawing conclusions. This is especially the case for markets in which the conventional SSNIP test loses much of its explanatory power, and non-price factors are to be taken into account.

\section{G. CONCLUSION}

The General Court's Servier judgment illustrates that its first ruling on reverse payment settlements in Lundbeck is not an exemption but a general rule. Its affirmation of Lundbeck's general rule is essentially unfair, because it may punish undertakings that have not behaved in an anticompetitive manner, and has a very restricted view of consumer welfare and how best to protect it, because it does not assign enough weight to possible negative effects on innovation. Until the Court of Justice rules on this issue, it is fair to say that the EU case law is particularly unsympathetic with originator companies, leaving the dangerous impression that undertakings cannot settle their own patent disputes when challenges arisen on the validity of the patent, or when the settlement agreements give that impression even though the parties, in reality, do not share such views.

Additionally, the Servier judgment provides no guidance on the issue of the relationship between pay-for-delay agreements and Article 102. Since the General Court ruled that the Commission had erred in its definition of the relevant market and thus its finding of market dominance, it leaves open the question whether a dominant undertaking pursuing a settlement strategy through reverse payments to generic companies would constitute abuse. 